\title{
HUBUNGAN TINGKAT PARTISIPASI DENGAN KEMANDIRIAN ANGGOTA PROGRAM KOPERASI PEMBIAYAAN EKONOMI KELURAHAN POSDAYA
}

\section{The Relationship between Levels of Participation with Independence of The Village Economic Financing Cooperative Program Posdaya Participants}

\author{
M. Khoirun Najib ${ }^{1)}$, dan Rilus A Kinseng ${ }^{1)}$ \\ 1) Departemen Sains Komunikasi dan Pengembangan Masyarakat, Fakultas Ekologi Manusia, Institut \\ Pertanian Bogor, Darmaga Bogor 16680, Indonesia \\ E-mail: muhammad.khoirunnajib00@yahoo.com; rilus@apps.ipb.ac.id
}

\begin{abstract}
Village Economic Financing Cooperative (KPEK) is one of the Posdaya programs that aimed at empowerment in economic development through entrepreneurship training and savings-and-loans activities to members of the program. This research aims to analyze the relationship of internal and external support factors with the level of participation, also to anaylze relationship between participation level with the level of independence KPEK Posdaya members. This research uses quantitative methods and supported by qualitative data. The results showed that internal factors such as age, education level, income level were significantly negative relation with the level of participation, but length became of a member of KPEK were significantly positive relation with the level of participation. The external factor; the quality of managerial interaction with members has moderate relationship with participation level of KPEK members, while service quality of manager to members has weak relationship with participation level. The result of statistical test also shows that the level of participation related to the level of independence KPEK Posdaya participant.
\end{abstract}

Keywords : empowerment, independence, KPEK Program, participation, Posdaya

\begin{abstract}
ABSTRAK
Koperasi Pembiayaan Ekonomi Kelurahan (KPEK) merupakan salah satu program Posdaya yang bertujuan untuk pemberdayaan dalam pengembangan di bidang ekonomi melalui kegiatan pelatihan kewirausahaan dan simpan pinjam kepada masyarakat anggota program. Penelitian ini bertujuan untuk menganalisis hubungan faktor pendukung internal dan eksternal dengan tingkat partisipasi serta hubungan tingkat partisipasi dengan tingkat kemandirian anggota KPEK Posdaya. Penelitian ini menggunakan metode kuantitatif yang didukung dengan data kualitatif. Hasil penelitian menunjukkan bahwa faktor internal yaitu usia, tingkat pendidikan, tingkat pendapatan berhubungan nyata negatif dengan tingkat partisipasi, namun lama menjadi anggota KPEK berhubungan nyata positif dengan tingkat partisipasi. Faktor eksternal, yaitu kualitas interaksi pengelola dengan anggota memiliki hubungan moderat dengan tingkat partisipasi anggota KPEK Posdaya, sedangkan pada kualitas pelayanan pengelola terhadap anggota memiliki hubungan yang lemah dengan tingkat partisipasi. Hasil uji statistik juga menunjukkan tingkat partisipasi berhubungan dengan tingkat kemandirian anggota KPEK Posdaya.
\end{abstract}

Kata Kunci : kemandirian, partisipasi, pemberdayaan, Posdaya, Program KPEK

\section{PENDAHULUAN}

Salah satu program pembangunan pemerintah dalam meningkatkan kesejahteraan adalah Pos Pemberdayaan Keluarga (Posdaya). Menurut Suyono dan Haryanto (2009) Posdaya sebagai forum informasi, pendidikan dan pemberdayaan serta penyegaran partisipasi masyarakat secara mandiri. Pada pelaksanaannya, Posdaya memiliki empat bidang kegiatan antara lain lingkungan, pendidikan, kesehatan, dan ekonomi. Salah satu program pemberdayaan dalam bidang ekonomi adalah koperasi. Menurut Muljono et al. (2009) Koperasi posdaya adalah sebagai wadah kegiatan ekonomi masyarakat yang nantinya mampu menumbuhkan perekonomian lokal. Pada Posdaya 
Puspa Lestari terdapat koperasi yang dinamakan Koperasi Pembiayaan Ekonomi Kelurahan Posdaya di Kampung Babakan Sukamantri Kelurahan Pasirkuda Kota Bogor. Sasaran dari Koperasi Pembiayaan Ekonomi Kelurahan (KPEK) ini ialah masyarakat yang kekurangan ekonomi dan berkeinginan berwirausaha, atau atas dasar keinginan masyarakat sekitar posdaya yang ingin ikut serta dalam koperasi ini.

Koperasi tentunya memerlukan partisipasi anggotanya dalam setiap kegiatan. Menurut Puspasari (2000) keragaan koperasi dapat memberikan manfaat ekonomi dan sosial bagi anggotanya yang menunjang pada tingkat partisipasi. Hal ini tercantum dalam UU No 25 tahun 1992 yang menyatakan bahwa dibentuknya koperasi guna meningkatkan kemandirian anggota koperasi terutama dalam hal memenuhi kebutuahan hidupnya.

Kemandirian anggota koperasi akan tumbuh jika diikuti dengan tingkat partisipasinya dalam setiap kegiatan. Penelitian sebelumnya Kurniawati (2010) dalam bidang ekonomi secara universal menunjukkan bahwa terdapat hubungan antara tingkat partisipasi dengan tingkat kemandirian Posdaya. Namun, hal ini bertolak belakang dengan hasil penelitian Nuryanti (2013) bahwa tingkat partisipasi dalam bidang Posdaya secara universal tidak berhubungan nyata dengan tingkat kemandirian. Berdasarkan penelitian-penelitian sebelumnya, penelitian ini meneliti mengenai hubungan tingkat partisipasi dengan tingkat kemandirian secara spesifik dalam program Koperasi Pembiayaan Ekonomi Kelurahan yang merupakan salah satu bidang ekonomi Posdaya. Program KPEK yang menjadi bagian dalam program Posdaya hanya terdapat 2 lokasi di Kota Bogor, salah satunya di Posdaya Puspa Lestari. Hal ini sesuai saran dari penelitian Kurniawati (2010) bahwa dilakukan penelitian lebih lanjut terkait tingkat partisipasi dan kemandirian dalam lingkup spesifik pada salah satu program di bidang ekonomi dalam penelitian ini KPEK Posdaya. Urgensi dibentuknya program KPEK di Posdaya Puspa Lestari ini adalah untuk memberikan modal usaha anggota dalam hal simpan pinjam, agar anggota mampu mandiri dalam ekonominya dengan usaha yang digelutinya. Hal ini dikaitkan akan menjadi kajian lebih lanjut dalam penelitian ini.

Rumusan masalah yang akan dikaji dalam penelitian ini yaitu: (1) bagaimana hubungan antara faktor internal (usia tingkat pendidikan, tingkat pendapatan dan lama menjadi anggota) dengan tingkat partisipasi anggota KPEK, (2) bagaimana hubungan faktor eksternal (kualitas interaksi dan kualitas pelayanan) dengan tingkat partisipasi anggota KPEK, (3) bagaimana hubungan antara tingkat partisipasi dengan tingkat kemandirian anggota KPEK.

Berdasarkan pada permasalahan yang dirumuskan, maka tujuan penelitian ini adalah 1) menganalisis hubungan antara faktor internal (usia tingkat pendidikan, tingkat pendapatan dan lama menjadi anggota) dengan tingkat partisipasi anggota KPEK, 2) menganalisis hubungan faktor eksternal (kualitas interaksi dan kualitas pelayanan) dengan tingkat partisipasi anggota KPEK dan 3) menganalisis hubungan antara tingkat partisipasi dengan tingkat kemandirian anggota KPEK.

\section{PENDEKATAN TEORITIS}

\section{Partisipasi Masyarakat}

Menurut Nasdian (2014) menjelaskan bahwa partisipasi adalah proses aktif, inisiatif diambil oleh warga komunitas sendiri, dibimbing oleh cara berfikir mereka sendiri, dengan menggunakan sarana dan proses (lembaga dan mekanisme) sehingga mereka dapat menegaskan kontrol secara efektif. Terdapat beberapa faktor yang mendorong partisipasi, menurut Pangestu (1995) terdiri dari 2 faktor yaitu internal dan eksternal. Faktor internal adalah yang mencakup karakteristik individu yang dapat mempengaruhi individu tersebut untuk berpartisipasi dalam suatu kegiatan. Faktor eksternal adalah faktor yang berada diluar individu yang dapat mempengaruhi individu tersebut untuk berpartisipasi dalam suatu kegiatan. Faktor Internal terdiri dari usia, tingkat pendidikan, tingkat pendapatan, lama tinggal. Pada faktor eksternal terdiri dari kualitas interaksi dan kualitas pelayanan pengelola terhadap anggota program. Menurut Sumantri et al. (2006), faktor internal lain yang mendorong partisipasi yaitu lama menjadi anggota program.

Tingkatan partisipasi merupakan keterlibatan masyarakat ataupun komunitas dalam sebuah program terlihat dari kesempatan masyarakat untuk terlibat dan mempengaruhi jalannya program. Selain itu, partisipasi dapat dilihat dari keikutsertaan dan keterlibatan aktif responden dalam setiap tahap partisipasi. Tahapan partisipasi masyarakat anggota program diukur dengan 
tingkatan partisipasi menurut Cohen dan Uphoff (1979). Cohen dan Uphoff (1979) membagi partisipasi ke beberapa tahapan, yaitu sebagai berikut:

(1) Partisipasi dalam pengambilan keputusan, berkaitan dengan masyarakat menuntut untuk ikut menentukan arah dan orientasi pembangunan. Wujud dari partisipasi ini antara lain seperti kehadiran rapat, diskusi, sumbangan pemikiran, tanggapan atau penolakan terhadap program yang ditawarkan.

(2) Partisipasi dalam pelaksanaan, meliputi menggerakkan sumber daya, dana, kegiatan administrasi, koordinasi dan penjabaran program.

(3) Partisipasi dalam menikmati hasil, melihat posisi masyarakat sebagai subjek pembangunan, maka semakin besar manfaat proyek dirasakan, berarti proyek tersebut berhasil mengenai sasaran.

(4) Partisipasi dalam evaluasi, dianggap penting sebab partisipasi masyarakat pada tahap ini merupakan umpan balik yang dapat memberi masukan demi perbaikan pelaksanaan proyek selanjutnya. Partisipasi dalam evaluasi, bentuk keikutsertaan masyarakat dalam menilai serta mengawasi kegiatan pembangunan serta hasilhasilnya. Penilaian ini dilakukan secara langsung, misalnya dengan ikut serta dalam mengawasi dan menilai atau secara tidak langsung, misalnya memberikan saran-saran, kritikan atau proses.

\section{Kemandirian masyarakat}

Nasdian (2014) menjelaskan bahwa dengan adanya partisipasi warga dalam suatu komunitas, diharapkan dapat mencapai suatu kemandirian. Suatu masyarakat yang merupakan anggota program dapat dikatakan mandiri jika sudah memenuhi beberapa kategori, yaitu: (1) kemandirian material; (2) kemandirian intelektual; dan (3) kemandirian manajemen. Kemandirian material adalah kemampuan produktif guna memenuhi kebutuhan materi dasar serta cadangan dan mekanisme untuk dapat bertahan pada waktu krisis. Kemandirian intelektual merupakan pembentukan dasar pengetahuan otonom oleh individu dalam komunitas yang memungkinkan mereka menanggulangi bentuk-bentuk dominasi yang lebih halus yang muncul diluar kontrol terhadap pengetahuan dan mampu memanfaatkan waktu dalam melakukan kegiatan. Kemandirian manajemen adalah kemampuan otonom untuk membina diri dan menjalani serta mengelola kegiatan kolektif agar ada perubahan dalam situasi kehidupannya. Hal tersebut sama halnya pendapat Sumodiningrat (1999) menyatakan kemandirian dapat diartikan sebagai proses pembangunan diciptakan dari, oleh dan untuk setiap anggota masyarakat. Kemandirian dalam hal ini menyangkut tiga segi, yaitu kemandirian material (tidak selalu berarti sanggup mencukupi kebutuhan sendiri, tetapi kemampuan produktif guna memenuhi kebutuhan dasar serta cadangan dan mekanisme bertahan pada saat krisis), kemandirian intelektual (pembentukan dasar yang memungkinkan menghindari dominasi pihak luar) dan kemandirian manajemen (kemampuan otonom untuk membina diri sendiri, menjalani serta mengelola kegiatan kolektif).

\section{Posdaya}

Satriani dan Muljono (2012) menyatakan bahwa Posdaya merupakan pemberdayaan dari, oleh dan untuk masyarakat. Pengertian ini memiliki maksud bahwa Posdaya sebagai sebuah program yang dibentuk oleh masyarakat, dijalankan oleh masyarakat dan diperuntukkan untuk masyarakat sehingga merupakan program yang bersifat bottom up atau bottom up programe. Program Posdaya terdiri dari 4 bidang yaitu, bidang ekonomi, bidang kesehatan, bidang lingkungan dan bidang pendidikan. Tujuan pembentukan Posdaya yaitu untuk menyegarkan modal sosial, seperti hidup bergotong-royong dalam masyarakat guna membantu pemberdayaan keluarga secara terpadu dan membangun keluarga bahagia dan sejahtera (Muljono et al. 2014).

\section{Koperasi Pembiayaan Ekonomi Kelurahan (KPEK)}

Kegiatan dibidang ekonomi pada Posdaya diarahkan pada pemberdayaan fungsi kewirausahaan. Salah satu program dibidang ekonomi Posdaya Puspa Lestari adalah KPEK. KPEK Posdaya fungsinya utamanya yakni sebagai sarana untuk pengembangan usaha anggota dalam bentuk peminjaman modal. Sasaran dari koperasi ini yakni anggota atau masyarakat yang memiliki ekonomi yang rendah akan tetapi ingin bermodal usaha, atau atas dasar keinginan masyarakat sekitar Posdaya yang ingin ikut serta dalam koperasi simpan pinjam. Tujuan dari program ini adalah untuk meningkatkan ekonomi masyarakat. Hal ini tercantum dalam UU RI No. 25 tahun 1992 tentang 
perkoperasian, salah satu fungsinya yaitu memperkokoh perekonomian rakyat. Selain itu, salah satu prinsip dalam koperasi adalah partisipatif dan kemandirian karena dikelola secara swadaya.

\section{Kerangka Pemikiran}

Pelaksanaan dalam program KPEK dikelola secara swadaya. Menurut Verhagen (1996) yang dikutip dalam Hikmat (2004), sarana untuk mencapai kemandirian adalah adanya keswadayaan. Swadaya adalah setiap tindakan sukarela yang dilakukan oleh seorang individu atau kelompok manusia yang bertujuan untuk pemuasan kebutuhan-kebutuhan atau aspirasi-aspirasi individual atau kolektif. Keswadayaan dalam pelaksanaan program KPEK Perlu didukung dengan keterlibatan anggota. Kerangka analisis dalam penelitian ini menjelaskan hubungan antara faktor internal (usia, tingkat pendidikan, tingkat pendapatan dan lama menjadi anggota) dengan tingkat partisipasi, hubungan antara faktor eksternal (kualitas interaksi pengelola dengan anggota dan kualitas pelayanan pengelola terhadap anggota) dengan tingkat partisipasi dan tingkat partisipasi dengan kemandirian anggota program KPEK Posdaya. Alur kerangka pemikiran dalam penelitian ini tersaji pada Gambar 1.

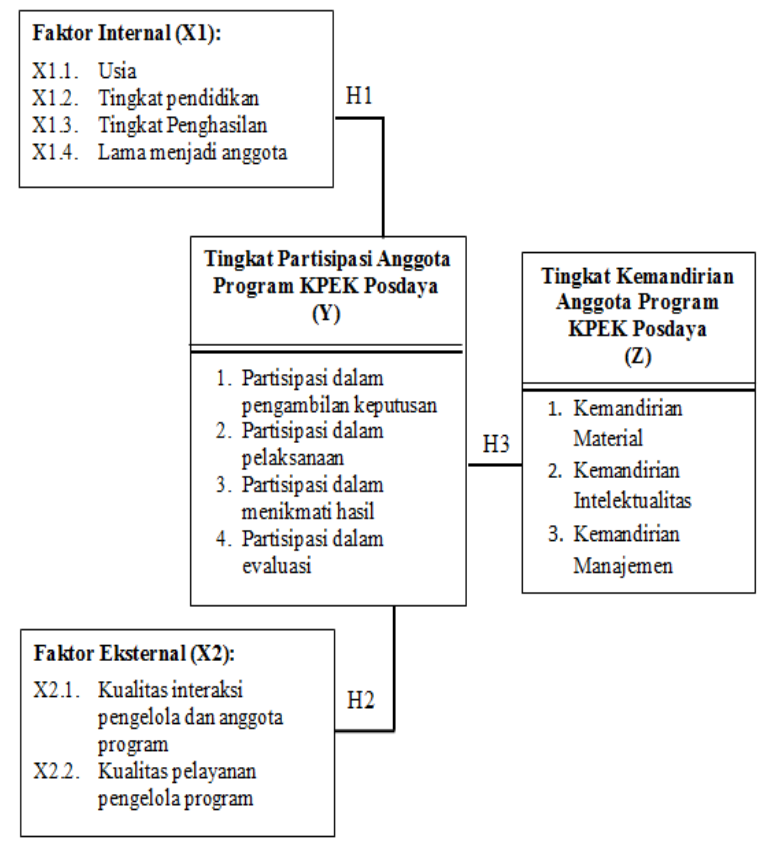

Keterangan: - hubungan

Gambar 1 Kerangka pemikiran penelitian
Penelitian ini termasuk explanatory (penjelasan), meneliti hubungan antarvariabel melalui pengujian hipotesis yang bertujuan untuk menguji suatu teori atau hipotesis guna memperkuat atau bahkan menolak teori atau hipotesis hasil penelitian yang sudah ada (Singarimbun et al. 2014). Data diperoleh dari kuisioner dan wawancara mendalam. Data primer adalah data tentang faktor internal, faktor eksternal, tingkat partisipasi dan tingkat kemandirian anggota KPEK Posdaya Puspa Lestari. Data sekunder didapatkan melalui penelusuran litelatur, dokumen resmi yang berkaitan dengan keadaan umum lokasi dan data-data yang relevan dengan penelitian.

Kegiatan penelitian ini dilaksanakan dalam jangka waktu lima bulan, terhitung mulai bulan Oktober 2017 sampai Januari 2018. Adapun lokasi penelitian dilakukan di Posdaya Puspa Lestari, RW 07 Babakan Sukamantri, Kelurahan Pasirkuda, Kota Bogor. Alasan pemilihan lokasi adalah Posdaya tersebut juara 2 tingkat nasional 2 tahun berturutturut. Selain itu juga program KPEK Posdaya Puspa Lestari menjadi percontohan di Kota Bogor.

Responden dalam penelitian ini adalah anggota KPEK Posdaya Puspa Lestari sebanyak 40 dari 140 orang. Pemilihan responden dilakukan dengan metode Simple Random Sampling yaitu secara acak dengan menggunakan software SPSS.Selain itu, pemilihan informan dilakukan secara sengaja (purposive). Adapun informan dalam penelitian ini adalah Kader KPEK, Kader Posdaya, Pihak RW/RT.

Data kuantitatif diolah menggunakan aplikasi Microsoft Excell 2010 dan SPSS version 16 for windows. Data tersebut dianalisis dengan menggunakan tabel frekuensi untuk masing-masing variabel secara tunggal. Kemudian SPSS version 16 for windows digunakan untuk uji statitistik rank Spearman untuk menganalisis ada atau tidaknya hubungan antar variabel dan juga melihat arah hubungan antar variabel tersebut.

\section{METODE PENELITIAN}

HASIL DAN PEMBAHASAN 


\section{Posdaya Puspa Lestari}

Posdaya Puspa lestari didirikan pada tanggal 28 oktober 2009 melalui kegiatan KKN Tematik bersama dengan P2SDM IPB. Adapun kegiatan dalam Posdaya Puspa Lestari terbagi menjadi 4 bidang yaitu sebagai berikut:

(1) Bidang pendidikan meliputi PAUD, Pelayanan Rehabilitasi Sosial Penyandang Cacat Bersama Masyarakat (PRSPCBM), Majelis Ta'lim.

(2) Bidang kesehatan meliputi Posyandu dan Posbindu.

(3) Bidang lingkungan meliputi bank sampah, laskar siaga dan biogas.

(4) Bidang Ekonomi meliputi KPEK, infaq dan sisa belanja dan home industry.

Posdaya Puspa Lestari memiliki banyak prestasi. Salah satu prestasi yang membanggakan adalah dua kali berturut-turut juara 2 lomba Posdaya tingkat nasional pada tahun 2014 dan 2015.

\section{Koperasi Pembiayaan Ekonomi Kelurahan (KPEK) Posdaya Puspa Lestari}

KPEK merupakan salah satu program dibidang ekonomi Posdaya. Program tersebut bertujuan untuk meningkatkan perekonomian anggota dengan memberikan pinjaman modal usaha. Adapun kegiatan lebih rinci dalam program KPEK di Posdaya Puspa Lestari adalah sebagai berikut:

(1) Simpan Pinjam

Simpan pinjam merupakan salah satu aktivitas dalam KPEK Posdaya. Modal bergulirnya perputaran uang berasal dari anggota dikelola secara swadaya. Simpanan dalam KPEK Posdaya terdiri dari:

a) Simpanan pokok, yaitu simpanan yang harus dibayarkan anggota saat awal mendaftar sebagai anggota. Besarnya jumlah simpanan pokok yang harus dibayarkan adalah sebesar Rp. 10 ribu.

b) Simpanan wajib, yaitu simpanan yang wajib dibayarkan setiap bulannya sebesar Rp 15 ribu.

c) Simpanan Sukarela, yaitu simpanan dalam bentuk tabungan anggota KPEK yang dapat diambil sewaktu waktu.

Selain kegiatan simpan, terdapat layanan pinjaman yang pengembaliannya dalam waktu jangka panjang yaitu selama 10 bulan. Besar kecilnya pemberian pinjaman didasarkan hanya atas tujuan meminjam yaitu untuk modal usaha.

(2) Pelatihan Kewirausahaan

Salah satu kegiatan yang diadakan oleh kader KPEK Posdaya Puspa Lestari adalah mengadakan pelatihan kewirausahaan. Pelatihan kewirausahaan tersebut meliputi pembuatan kue, produksi tempe, kerajinan tangan dari sampah, membuat tanaman hias dalam pot, cara ternak lele dan lain lain.

(3) Rencana Kerja dan Rencana Anggaran Pendapatan dan Belanja (RK-RAPB)

Kegiatan RK-RAPB merupakan kegiatan yang senagaja diadakan sebagai bentuk perencanaan dan evaluasi terhadap koperasi selama setahun terakhir. Kegiatan tersebut diikuti oleh semua anggota KPEK. Pengadaan RK-RAPB agar keputusan yang diambil bersama dilakukan secara musyawarah mufakat dan bersamaan dilaporkan modal dari koperasi serta laporan hasil SHU setiap anggota KPEK Posdaya.

\section{Hubungan Faktor Internal dengan Tingkat Partisipasi}

Faktor internal yang diukur dalam penelitian ini yaitu: usia, tingkat pendidikan, tingkat pendapatan dan lama menjadi anggota dalam program KPEK. Hubungan antara faktor internal dengan tingkat partisipasi dapat dilihat secara lebih jelas pada Tabel 1.

Tabel 1 Nilai koefisien korelasi antara faktor internal dengan tingkat partisipasi

\begin{tabular}{llc}
\hline \multirow{2}{*}{ Faktor Internal } & \multicolumn{2}{c}{ Tingkat Partisipasi } \\
\cline { 2 - 3 } & \multicolumn{1}{c}{$\boldsymbol{r}_{\boldsymbol{s}}$} & Sig. \\
\hline Usia & $-0.447^{*}$ & 0.039 \\
\hline $\begin{array}{l}\text { Tingkat } \\
\text { Pendidikan }\end{array}$ & $-0.333^{*}$ & 0.041 \\
\hline $\begin{array}{l}\text { Tingkat } \\
\text { Pendapatan }\end{array}$ & $-0.296^{*}$ & 0.047 \\
\hline $\begin{array}{l}\text { Lama menjadi } \\
\text { anggota }\end{array}$ & $0.342^{* *}$ & 0.030 \\
\hline \multirow{2}{*}{ *. Correlation is significant at the 0.05 level (1-tailed). } \\
${ }^{* *}$. Correlation is significant at the 0.01 level (1-tailed).
\end{tabular}

Variabel pada faktor internal meliputi usia, tingkat pendidikan, tingkat pendapatan dan lama menjadi anggota terdapat hubungan yang signifikan terhadap tingkat partisipasi. Nilai koefisien korelasi pada usia, tingkat pendidikan dan tingkat pendapatan dengan tingkat partisipasi bernilai negatif (-), artinya hubungan antar kedua variabel tersebut tidak searah. 
Pada usia dengan tingkat partisipasi memiliki hubungan nyata negatif. Anggota KPEK dengan kategori usia dewasa awal dan dewasa sedang cenderung memiliki tingkat partisipasi tinggi. Hal ini dibuktikan dengan anggota usia awal dan dewasa pertengahan lebih aktif dindingkan dengan dewasa tua. Hal ini sesuai dengan pernyataan Nurkatamso dan Listyaningsih (2013) yang menyatakan bahwa usia produktif mempengaruhi tingkat partisipasi lebih aktif dalam program pemberdayaan. Oleh karena itu dapat disimpulkan semakin muda usia anggota KPEK, tingkat partisipasinya cenderung akan tinggi.

Berdasarkan hasil uji rank Spearman, tingkat pendidikan dengan tingkat partisipasi memiliki hubungan nyata negatif. Berdasarkan data dilapang bahwa anggota yang memiliki tingkat pendidikan rendah cenderung memiliki pendapatan rendah pula sehingga membutuhkan modal usaha untuk memenuhi kebutuhan hidupnya. Hal ini selaras dengan hasil rank Spearman antara tingkat pendapatan dengan tingkat partisipasi, program KPEK sudah tepat sasaran karena anggota sebagian besar berasal dari tingkat pendapatannya rendah dan sedang. Adapun keikutsertaan dalam program KPEK dilatarbelakangi oleh tuntutan ekonomi.

Berdasarkan hasil uji statistik pada Tabel 1 menunjukkan bahwa lamanya menjadi anggota dalam program berhubungan nyata positif dengan tingkat partisipasi. Semakin lama bergabung menjadi anggota dalam program KPEK semakin tinggi tingkat partisipasinya. Hal ini sesuai dengan fakta dilapang bahwa anggota yang lebih lama mengikuti program KPEK lebih merasakan manfaatnya lebih dulu, tidak hanya manfaat ekonomi yang dirasakan namun juga manfaat secara sosial berupa silaturahmi antar anggota sehingga akan lebih aktif dalam kegiatan. Hal ini selaras dengan penelitian Sumantri et al. (2006) bahwa anggota yang sudah lama menjadi anggota dalam program Unit Pengelolaan Keuangan Desa (UPKD) akan lebih berpartisipasi karena sudah merasakan manfaat yang dirasakannya. Selain itu, dalam penelitian tersebut juga menunjukkan anggota yang sudah lama menjadi anggota dalam UPKD akan lebih merasa memiliki terhadap program tersebut.

\section{Hubungan Faktor Eksternal dengan Tingkat Partisipasi}

Faktor eksternal yang diukur dalam penelitian ini yaitu: kualitas interaksi antara pengelola dengan anggota dan kualitas pelayanan pengelola terhadap anggota. Hubungan antara faktor eksternal dengan tingkat partisipasi dapat dilihat secara lebih jelas pada Tabel 2.

Tabel 2 Nilai koefisien korelasi antara faktor eksternal dengan tingkat partisipasi

\begin{tabular}{lcc}
\hline \multirow{2}{*}{ Faktor Internal } & \multicolumn{2}{c}{ Tingkat Partisipasi } \\
\cline { 2 - 3 } & $\boldsymbol{r}_{\boldsymbol{s}}$ & Sig. \\
\hline Kualitas & $0.406^{* *}$ & 0.009 \\
Interaksi & 0.268 & 0.095 \\
\hline $\begin{array}{l}\text { Kualitas } \\
\text { Pelayanan }\end{array}$ & \\
\hline $\begin{array}{l}\text { *. Correlation is significant at the } 0.05 \text { level (2-tailed). } \\
\text { **. Correlation is significant at the } 0.01 \text { level (2-tailed). }\end{array}$
\end{tabular}

Hasil uji rank Spearman antara kualitas interaksi dengan tingkat partisipasi memiliki hubungan yang signifikan. Nilai signifikansi yang dihasilkan sebesar 0.095. Hal ini karena p-value (sign.(2tailed $))<(\alpha(0.05))$ maka tolak Ho, artinya nilai korelasi yang dihasilkan antara kualitas interaksi dengan tingkat partisipasi menunjukkan terdapat hubungan signifikan antara kedua variabel tersebut. Interaksi antara pengelola dengan anggota KPEK terjain rutin, yaitu setiap bulan sekali. Selain itu, adanya pertemuan rutin anggota KPEK dapat menerima informasi langsung dari kader setiap bulan sekali. Hal ini selaras dengan teori Ropke (2000) yang dikuti Setiawan (2004) bahwa salah satu kualitas partisipasi dalam program koperasi sangat dipengaruhi oleh interaksi pengelola dan anggota dalam hal memanajemen koperasi maupun dalam kegiatan program.

Berbeda dengan hasil korelasi kualitas interaksi, hasil uji rank Spearman menunjukkan tidak terdapat hubungan anatara kualitas interaksi dengan tingkat partisipasi. Berdasarkan hasil di lapang bahwa penilaian responden terhadap kualitas pelayanan pengelola sudah sangat baik dalam hal kesesuaian melaksanakan tugas, memenuhi kebutuhan, transparansi pendanaan dan penjelasan infromasi baik mengenai KPEK sehingga responden kurang dapat melihat kekurangan dari pelayanan pengelolaan KPEK. Salah satu bentuk pelayanan yaitu memenuhi kebutuhan dengan memberikan manfaat ekonomi bagi anggota KPEK berupa pengadaan pelatihan kewirausahaan. Pelatihan tersebut dilatarbelakangi oleh keinginan anggota untuk memiliki keterampilan, kemudian adanya pelatihan tersebut diharapkan menjadi usaha nantinya. Peningkatan partisipasi anggota program diperlukan berbagai langkah yang dapat menarik 
anggota untuk berkontribusi seperti peningkatan pelayanan dengan adanya peningkatan manfaat ekonomi yang akan dirasakan anggota (Wijajanti 2011). Hal ini sangat terlihat jelas bahwa program KPEK ini memberikan manfaat secara ekonomi. Meskipun pelayanan pengelola dinilai baik terhadap anggota, pelayanan juga terkendala modal yang ada, meskipun modalnya sudah tinggi namun juga diikuti banyaknya anggota sehingga perputaran dalam pinjaman masih terkendala

\section{Hubungan Tingkat Partisipasi dengan Tingkat Kemandirian Anggota KPEK}

Partisipasi merupakan hal terpenting dalam berlangsungnya dan berjalannya program. Partisipasi responden dalam kegiatan KPEK Posdaya merupakan sebuah proses pembelajaran dalam meningkatkan kemandiriannya. Menurut Nasdian (2014) menjelaskan bahwa dengan adanya partisipasi warga dalam suatu komunitas, diharapkan dapat mencapai kemandirian. Hasil temuan di lapang bahwa semakin tinggi tingkat partisipasi anggota dalam kegiatan program KPEK mulai dari pengambilan keputusan, pelaksanaan, menikmati hasil dan evaluasi diikuti dengan tinggi juga pada tingkat kemandirian.

Tingkat partisipasi anggota KPEK Posdaya tergolong pada kategori sedang dan tinggi dengan proporsi persentase yang sama yaitu 50 persen, sedangkan pada tingkat kemandirian anggota KPEK Posdaya tergolong pada kategori sedang dan tinggi dengan proporsi yang berbeda yaitu sebanyak 55 persen dan 45 persen. Hasil uji korelasi rank Spearman antara tingkat partisipasi pada setiap tahapan dengan tiap kemandirian dapat dilihat pada Tabel 3.

Berdasarkan hasil uji rank Spearman tersebut menunjukkan hubungan signifikan adalah partisipasi dalam pengambilan keputusan dengan kemandirian intelektual dan partisipasi dalam pelaksanaan dengan kemandirian manajemen, masing-masing memiliki nilai koefisien korelasi sebesar $0.326^{*}$ dan $0.485^{* *}$.

Tabel 3 Korelasi Spearman (rs) antara tingkat partisipasi dengan tingkat kemandirian responden

\begin{tabular}{lccc}
\hline Tingkat & \multicolumn{3}{c}{ Tingkat Kemandirian } \\
\cline { 2 - 4 } Partisipasi & Intelektual & Material & Manajemen \\
\hline $\begin{array}{l}\text { Pengambilan } \\
\text { keputusan }\end{array}$ & $0.326^{*}$ & 0.137 & 0.130 \\
\hline
\end{tabular}

\begin{tabular}{lccc}
\hline Pelaksanaan & 0.196 & 0.227 & 0.485 \\
\hline $\begin{array}{l}\text { Menikmati } \\
\text { hasil }\end{array}$ & -0.185 & 0.094 & 0.249 \\
\hline Evaluasi & 0.199 & -0.045 & -0.193 \\
\hline Keterangan : **. correlation is significant at the 0.01 (2-tailed)
\end{tabular}

Hubungan keduanya tergolong dalam kategori hubungan moderat dan adanya $(*)$ menunjukkan hubungan kedua variabel tersebut signifikan. Adapun jika dilihat secara keseluruhan hubungan antara tingkat partisipasi dengan tingkat kemandirian anggota KPEK Posdaya dapat dilihat hasil uji statistik rank Spearman yang tersedia pada Tabel 4.

Tabel 4 Nilai koefisien korelasi Spearman (rs) antara tingkat partisipasi dengan tingkat kemandirian responden

\begin{tabular}{|c|c|c|}
\hline & \multicolumn{2}{|c|}{ Tingkat Kemandirian } \\
\hline & $r_{s}$ & Sig. \\
\hline $\begin{array}{l}\text { Tingkat } \\
\text { Partisipasi }\end{array}$ & $0.332 *$ & 0.036 \\
\hline
\end{tabular}

Berdasarkan hasil temuan di lapang bahwa dukungan anggota terhadap program KPEK Posdaya ini tinggi dibuktikan dengan keterlibatan responden pada setiap tahapan partisipasi baik pengambilan keputusan, pelaksanaan, menikmati hasil dan evaluasi. Hal ini karena manfaat yang dirasakan secara langsung baik dalam bidang eknomi maupun sosial. Manfaat bidang ekonomi yang didapatkannya adalah kemudahan simpanan, pinjaman modal usaha dan pelatihan kewirausahaan. Manfaat yang dirasakan tidak hanya di bidang ekonomi saja namun juga di bidang sosial, misalnya mampu menjalin relasi dengan sesama anggota program KPEK. Relasi yang dimaksud responden adalah sebagai sarana silaturahmi antar anggota di lingkungan sosial masyarakat. Kedua bidang tersebut mendorong kemandirian anggota KPEK Posdaya Puspa Lestari. Hal ini selaras dengan pernyataan Sumardjo (1999), kemandirian anggota program akan terwujud bila kualitas perilaku masyarakat cukup tinggi untuk mendukung program tersebut yang dibuktikan dengan keikutsertaan dalam program.

Sebagian besar anggota KPEK berpartisipasi dalam menikmati hasil tinggi salah satu alasannya karena manfaat secara langsung diterima anggota program, salah satu manfaatnya adalah ekonomi. Manfaat ekonomi yang diterima oleh anggota KPEK Posdaya berupa peminjaman modal usaha dan 
simpanan. Sebagian besar anggota KPEK meminjam modal untuk membangun usaha. Hal tersebut menunjukkan sebagai bentuk kemandirian dalam material, yaitu kemampuan produktif dengan membangun usaha guna memenuhi kebutuhan hidupnya. Selain itu, sebagian besar anggota KPEK juga aktif berpartisipasi dalam melakukan simpanan dalam program KPEK. Hal tersebut juga merupakan salah satu bentuk kemandirian material yaitu memiliki tabungan/cadangan yang dapat digunakan sewaktu-waktu, misalnya saat lebaran tiba maupun saat menjelang tahun ajaran baru siswa sekolah. Pernyataan tersebut selaras menurut Sumodiningrat (1999) yaitu kemandirian material dapat berupa kemampuan produktif guna memenuhi kebutuhan dasar dan cadangan serta mekanisme bertahan pada saat krisis.

Kemandirian manajemen dapat dilihat dari melaksanakan dan mengelola kegiatan secara kolektif (Pangestu 1995). Kemandirian manajemen anggota KPEK Posdaya dilatarbelakangi karena anggota KPEK Posdya juga merupakan anggota Posdaya sehingga hubungannya sudah terjalin sebelumnya. Kemandirian manajemen anggota dalam program KPEK Posdaya dapat dilihat dari partisipasi anggota KPEK dalam pelaksanaan pelatihan kewirausahaan, sejalan dengan anggota sudah mampu melakukan tindakan kolektif bersama. Sebelum pelaksanaan pelatihan kewirausahaan diadakan rapat untuk melakukan persiapan alat dan bahan yang dibutuhkan. Terkait bahan bahan yang akan digunakan, anggota yang hadir diberikan tugas masing-masing.

Partisipasi yang diikuti dalam kegiatan KPEK semata-mata bertujuan untuk keluar dari permasalahan ekonomi dalam mencapai kemandiriannya. Pada partisipasi dalam pengambilan keputusan yang tinggi cenderung kemandirian intelektualnya tinggi. Hal ini sesuai dengan dilapang bahwa responden yang memiliki ide dalam membuat usaha baru (inovasi), didapatkan dari hasil pelatihan kewirausahaan yang diikutinya. Selain itu, kemampuan anggota dalam mengelola waktu untuk kegiatan KPEK ditunjukkan dengan kehadirannya dalam kegiatan rapat seperti RK-RAPB, artinya mampu membagi waktu dalam usaha dan rapat. Oleh karena itu, dalam penelitian ini secara kuantitatif maupun data kualitatif menunjukkan adanya hubungan antara tingkat partisipasi dengan tingkat kemandirian anggota KPEK Posdaya Puspa Lestari

\section{SIMPULAN DAN SARAN}

\section{Simpulan}

Berdasarkan hasil penelitian, dapat dibuat beberapa kesimpulan, sebagai berikut:

1. Faktor internal pendorong partisipasi meliputi karakteristik anggota KPEK Posdaya seperti usia, tingkat pendidikan, tingkat pendapatan dan lama menjadi anggota program KPEK memiliki hubungan nyata terhadap tingkat partisipasi, namun nilai koefisien korelasi antara usia, tingkat pendidikan dan pendapatan dengan tingkat partisipasi didapatkan nilai koefisien korelasi negatif (-) artinya hubungannya tidak searah. Hal ini karena usia yang berpartisipasi dalam program cenderung usia dewasa awal dan pertengahan dan dapat disimpulkan semakin usia produktif maka semakin tinggi tingkat partisipasinya dalam kegiatan program KPEK. Anggota KPEK yang memiliki tingkat pendidikan kategori rendah cenderung tingkat pendapatannya rendah pula dan tingkat pendapatan rendah cenderung memiliki partisipasi yang tinggi dalam kegiatan. Hal ini karena tuntutan ekonomi untuk memenuhi kebutuhan hidup sehingga mengikuti kegiatan dalam program KPEK.

2. Pada faktor eksternal, kualitas interaksi pengelola dan anggota dengan tingkat partisipasi terdapat hubungan nyata positif. Artinya semakin tinggi kualitas interaksi yang terjalin antara pengelola program dengan anggota maka semakin tinggi tingkat partisipasi. Penilaian anggota terhadap kualitas interaksi yang terjalin antara KPEK Posdaya dengan anggota sudah terjalin dengan baik. Pengelola dalam hal ini kolektor yang rutin mendatangi ke setiap rumah anggota, sehingga informasi mengenai KPEK dapat tersampaikan dengan baik kepada anggota. Selain itu, di setiap RT terdapat kolektor sehingga interaksi langsung dan kerjasama dapat terjalin dengan baik. Hasil ini berbeda dengan hasil korelasi antara kualitas pelayanan pengelola terhadap anggota dengan tingkat partisipasi tidak memiliki hubungan yang nyata. Hal ini dikarenakan meskipun pengelola program memberikan pelayanan yang baik, namun terkendala dengan modal yang terbatas dan tidak diimbangi dengan banyaknya jumlah anggota.

3. Tingkat partisipasi responden berhubungan nyata positif dengan tingkat kemandiriannya. Anggota yang aktif dan mampu memanfaatkan 
kegiatan dalam program KPEK erat kaitannya dengan kemampuan produktif usahanya. Oleh karena itu, dapat disimpulkan bahwa semakin tinggi tingkat partisipasi anggota dalam kegiatan program KPEK maka semakin tinggi tingkat kemandiriannya.

\section{Saran}

Berdasarkan hasil penelitian, maka dapat ditarik beberapa hal yang dapat dijadikan masukan atau saran diantaranya sebagai berikut:

1. Pengelola KPEK Posdaya, tetap menjaga kualitas interaksi dan pelayanan terhadap anggota untuk mendorong partisipasi anggota dalam kegiatan. Selain itu, meningkatkan fasilitas dalam hal pelatihan kewirausahaan dan pemasaran usaha-usaha yang dimiliki oleh anggota program KPEK Posdaya serta terdapat sarana yang menaungi usaha-usaha anggota KPEK.

2. Akademisi, diperlukan penelitian lebih lanjut mengenai faktor-faktor lain yang mendorong partisipasi faktor-faktor lain yang dapat mempengaruhi tingkat kemandirian program KPEK Posdaya. Selain itu perlu penelitian lebih lanjut mengenai program KPEK diluar program Posdaya.

3. Masyarakat khususnya anggota program, adanya kesadaran bahwa partisipasi dalam evaluasi juga penting. Pada tahap partisipasi dalam evaluasi juga akan memberikan manfaat pada anggota, tentunya diikuti dengan perbaikan kualitas program dan akan menjadi bahan koreksi dan perbaikan untuk kedepannya agar program tetap berjalan (sustainable).

\section{DAFTAR PUSTAKA}

Cohen JM, Uphoff NT. 1979. Participation's place in rural development: seeking clarity through specificity. [Diunduh 17 September 2017]. Tersedia pada: https://www.researchgate.net/publication/ 4897194_Participation's_Place_in_Rural Development_Seeking_Clarity_Through_ Specificity.

Hikmat H. 2004. Strategi Pemberdayaan Masyarakat. Bandung (ID): Humaniora Utama Press.
Kurniawati D. 2010._Tingkat partisipasi dan kemandirian masyarakat dalam bidang ekonomi program posdaya [Tesis]. Bogor (ID): Institut Pertanian Bogor.

Muljono P, Burhanudin dan Bakhtiar Y. 2009. Upaya pemberdayaan masyarakat dan pengentasan kemiskinan melalui model Posdaya (Pos Pemberdayaan Keluarga). [Prosiding Seminar Hasil]. [diunduh pada tanggal 20 September 2017]. Tersedia pada alamat: http://repository.ipb.ac.id/bitstream/handle /123456789/71511/Bidang\%20vi\%20sose k.pdf? sequence $=1 \&$ isAllowed $=$ y.

Muljono P, Mintarti MYB, Dewi P. 2014. 101 Cara Mengenal Posdaya. Bogor (ID): IPB Press.

Nasdian FT. 2014. Pengembangan Masyarakat. Jakarta (ID): Yayasan Pustaka Obor Indonesia.

Nurkatamso A, Listyaningsih U. 2013. Tingkat partisipasi masyarakat dalam program fisik Program Nasional Pemberdayaan Masyarakat Mandiri (PNPM) pedesaan di Kecamatan Nanggulan Kabupaten Kulonprogo, Yogyakarta. Jurnal Bumi Indonesia [Internet]. [diunduh tanggal 25 Maret 2017]; 2(1): 63-67. Tersedia pada alamat: http://lib.geo. ugm.ac.id /ojs/index.php/jbi/article/view/164/161

Nuryanti T. 2013. Hubungan antara tingkat partisipasi dengan tingkat kemandirian masyarakat peserta Posdaya. [Skripsi]. Bogor (ID): IPB.

Pangestu MHT. 1995. Partisipasi masyarakat dalam pelaksanaan Kegiatan perhutanan Sosial (Studi Kasus: KPH Cianjur, Jawa Barat). [Tesis]. Bogor (ID): Pascasarjana IPB.

Puspasari SL. 2000. Analisis Keragaan Koperasi dan Tingkat Partisipasi Anggota KUD Giri Tani. [Skripsi]. Bogor (ID): Institut Pertanian Bogor.

Satriani I, Muljono P. 2012. Komunikasi partisipatif pada program pos pemberdayaan keluarga. Jurnal Masyarakat Kebudayaan dan Politik. [Internet]. [dikutip tanggal 30 Agustus 2017]. 2(5): 87-95. Tersedia pada alamat: 
http://repository.ipb.ac.id/bitstream/handle /123456789/52068/2 0 11isa.pdf

Setiawan AH. 2004. Peningkatan partisipasi anggota dalam rangka menunjang pengembangan usaha koperasi. Jurnal Dinamika Pembangunan [Internet]. [diunduh pada tanggal 10 Januari 2018]; 1(1): 39-44. Tersedia pada alamat: http://eprints.undip.ac.id/13970/

Singarimbun M et al. 2014. Metode Penelitian Survei. Effendi S dan Tukuran, editor. Jakarta (ID): LP3ES.

Sumantri B, Cahyadinata I, Surbakti A. Nalisis faktor-faktor yang berhubungan dengan tingkat partisipasi anggota UPKD pasca proyek BRDP (Studi Kasus UPKD Sidodadi di Desa Sidodadi Kec. Pondok Kelapa Kab. Bengkulu Utara). Jurnal Sosial Ekonomi UNIB.[Internet]. [diunduh pada tanggal 31 Januari 2018]. Tersedia pada alamat: https://media.neliti.com/media/publication s/73470-IDanalisis-faktorfaktor-yang berhubungan.pdf

Sumardjo. 1999. Transformasi penyuluhan pertanian menuju pengembangan kemandirian petani (Kasus di Propinsi Jawa Barat) [Disertasi]. Bogor (ID): Institut Pertanian Bogor.

Sumodiningrat G. (1999). Pemberdayaan Masyarakat dan Jaring Pengaman Sosial. Jakarta (ID): Gramedia.

Suyono H, Haryanto, R. 2009. Buku Pedoman Pembentukan dan Pengembangan Pos Pemberdayaan Keluarga (Posdaya). Jakarta (ID): Balai Pustaka.

Undang-undang Nomor 25 Tahun 1992 tentang Pengkoperasian. Tersedia pada alamat: http://www.ikopin.ac.id/wpcontent/uploads/2015/07/UU-Nomor -25tahun-1992-tentang-Perkoperasian.pdf 